\title{
Application of the Environmental Seismic Intensity scale (ESI 2007) and the European Macroseismic Scale (EMS-98) to the Kalamata (SW Peloponnese, Greece) earthquake $(\mathrm{Ms}=6.2$, September 13, 1986) and correlation with neotectonic structures and active faults
}

\author{
Ioannis G. Fountoulis, Spyridon D. Mavroulis ${ }^{\star}$
}

National and Kapodistrian University of Athens, Faculty of Geology and Geoenvironment, Department of Dynamic Tectonic Applied Geology, Panepistimiopolis, Athens, Greece

\author{
Article history \\ Received October 16, 2012; accepted June 11, 2013. \\ Subject classification: \\ Neotectonics, Earthquake environmental effects, ESI 2007 intensity scale, EMS-98 intensity scale, Kalamata earthquake.
}

\begin{abstract}
On September 13, 1986, a shallow earthquake (Ms=6.2) struck the city of Kalamata and the surrounding areas (SW Peloponnese, Greece) resulting in 20 fatalities, over 300 injuries, extensive structural damage and many earthquake environmental effects (EEE). The main shock was followed by several aftershocks, the strongest of which occurred two days later (Ms=5.4). The EEE induced by the 1986 Kalamata earthquake sequence include ground subsidence, seismic faults, seismic fractures, rockfalls and hydrological anomalies. The maximum ESI 2007 intensity for the main shock has been evaluated as IX $X_{E S I ~ 2007}$, strongly related to the active fault zones and the reactivated faults observed in the area as well as to the intense morphology of the activated Dimiova-Perivolakia graben, which is a 2nd order neotectonic structure located in the SE margin of the Kalamata-Kyparissia mega-graben and bounded by active fault zones. The major structural damage of the main shock was selective and limited to villages founded on the activated Dimiova-Perivolakia graben $\left(I X_{E M S-98}\right)$ and to the Kalamata city (IX $\left.X_{E M S-98}\right)$ and its eastern suburbs $\left(I X_{E M S-98}\right)$ located at the crossing of the prolongation of two major active fault zones of the affected area. On the contrary, damage of this size was not observed in the surrounding neotectonic structures, which were not activated during this earthquake sequence. It is concluded that both intensity scales fit in with the neotectonic regime of the area. The ESI 2007 scale complemented the EMS-98 seismic intensities and provided a completed picture of the strength and the effects of the September 13, 1986, Kalamata earthquake on the natural and the manmade environment. Moreover, it contributed to a better picture of the earthquake scenario and represents a useful and reliable tool for seismic hazard assessment.
\end{abstract}

\section{Introduction}

The twelve degrees macroseismic intensity scales, developed since the beginning of the 20th century, were based on evaluation of the earthquake effects on humans, manmade structures and the natural environment. However, in the early versions of these scales, the earthquake effects on the natural environment were scarcely included. Their presence in the scale was mostly due to many references to ground cracks, landslides and landscape modifications contained in the historical reports [Guerrieri and Vittori 2007]. Later, in the second half of the 20th century, these effects have been increasingly disregarded in the literature and the practice of macroseismic investigations, while increasing attention has been directed towards the analysis of the effects on humans and manmade structures [Gosar 2012].

The EMS-98 scale, which is nowadays predominantly used in Europe, considers three categories of effects: (a) on humans, (b) on objects and on nature and (c) damage to buildings [Grünthal 1998]. Its basic advantage in comparison to previous scales is a definition of vulnerability classes for buildings and more precise statistical treatment of collected macroseismic data [Grünthal 1998]. This quantification is elaborated in details for the first three effects, but not for the effects on nature which are rather briefly summarized in a table in EMS-98 scale. Effects on nature, summed up in the EMS-98 scale by the term "seismogeological" effects, are divided into four groups: (a) hydrological effects, including changes in the well water level, waves on standing water from local shaking, lake water turbidity, changes in the flow of springs and overflow of lakes, (b) slope failure effects, including landslides and rockfalls, (c) processes on flat ground, including cracks and 
fissures as well as (d) convergent processes (complex cases) such as landslides (hydrological) and liquefaction phenomena [Grünthal 1998]. This latter group covers instances where more than one type of process is involved in producing the effect. For each type of effects three intensity ranges are presented in tabular form: (a) the possible range of observations, (b) the range of intensities that is typical for this effect, and (c) the range of intensities for which this effect is most usefully employed as diagnostic [Grünthal 1998].

The effects of earthquakes on the ground have often been included in intensity scales but are in practice quite hard to benefit from [Grünthal 1998]. This is because these effects are complex, and are often influenced by various factors such as inherent slope stability, level of water table, etc., which may not be readily apparent to the observer. The result is that most of these effects can be seen at a wide range of intensity degrees which prevents its practical use in intensities assessment [Grünthal 1998].

Nevertheless, recent studies [Dengler and McPherson 1993, Serva 1994, Dowrick 1996, Esposito et al. 1997, Hancox et al. 2002, Michetti et al. 2004, 2007, Castilla and Audemard 2007, Serva et al. 2007, Silva et al. 2008, Reicherter et al. 2009] have offered new substantial evidence that coseismic environmental effects provide precious information on the earthquake size and its intensity field, complementing the traditional damage-based macroseismic scales. As a matter of fact, with the outstanding growth of paleoseismology as a new independent discipline, nowadays the effects on the environment can be described and quantified with a remarkable detail compared with that available at the time of the earlier scales. Therefore, today the definition of the intensity degrees can effectively take advantage of the diagnostic characteristics of the effects on the natural environment.

Earthquake environmental effects (EEE) are any effect produced by a seismic event on the natural environment [Michetti et al. 2007]. The coseismic environmental effects considered more diagnostic for intensity evaluation can be categorized in two main types: (a) Primary effects, which are the surface expressions of the seismogenic tectonic source, including surface faulting, surface uplift and subsidence and any other surface evidence of coseismic tectonic deformation; (b) Secondary effects, which include phenomena generally induced by the ground shaking [Michetti et al. 2007] and are conveniently classified into eight main categories that are hydrological anomalies, anomalous waves including tsunamis, ground cracks, slope movements, tree shaking, liquefaction, dust clouds and jumping stones [Michetti et al. 2007].
The use of EEE for intensity assessment has been recently promoted by the Environmental Seismic Intensity scale (ESI 2007) since it will unquestionably provide an added value to traditional intensity evaluations (i) allowing the accurate assessment of intensity in sparsely populated areas, (ii) providing a reliable estimation of earthquake size with increasing accuracy towards the highest levels of the scale, where traditional scales saturate and ground effects are the only ones that permit a reliable estimation of earthquake size, and (iii) allowing comparison among future, recent and historical earthquakes [Michetti et al. 2004]. In addition, some environmental morphogenetic effects (either primary or secondary) can be stored in the palaeoseismological record, allowing the expansion of the time window for seismic hazard assessment up to tens of thousands of years [Guerrieri et al. 2007, Porfido et al. 2007]. Furthermore, the EEE are not influenced by human parameters such as effects on people and the manmade environment as the traditional intensity scales (MCS, MM, EMS 1992, etc.) predominantly have built in.

This paper focuses on the September 13, 1986, Kalamata earthquake that affected the Kalamata area located in Messinia (SW Peloponnese, Greece). It aims to: (a) the presentation of the geotectonic and seismotectonic regime of the earthquake affected region based on field data, (b) the presentation of the earthquake induced environmental effects and structural damage, (c) the seismic intensity assignments for the September 13, 1986, Kalamata earthquake based on the guidelines of the Environmental Seismic Intensity scale (ESI 2007) [Michetti et al. 2007] and the European Macroseimic Scale (EMS-98) [Grünthal 1998], (d) the determination of their geographical distribution, (e) the interpretation of the intensity values data and their distribution to the neotectonic structures and the active fault zones of the area as well as at (f) the conduction of a comparative evaluation review on the application of both ESI 2007 and EMS 98 scales.

\section{Geological setting}

The geological formations in the wider Kalamata area can be divided into two major categories: alpine and post-alpine (Figure 1).

\subsection{Alpine formations}

The following four alpine geotectonic units occur from bottom to top [Mariolakos et al. 1986, Psonis 1986] (Figure 2a,b): (a) the Mani unit consisting mainly of Upper Senonian-Upper Eocene marbles and Upper Eocene-Upper Oligocene flysch-transition beds, (b) the Arna unit comprising phyllites and quartzites, (c) the Tripolis unit which consists of the Tyros beds, the Cre- 

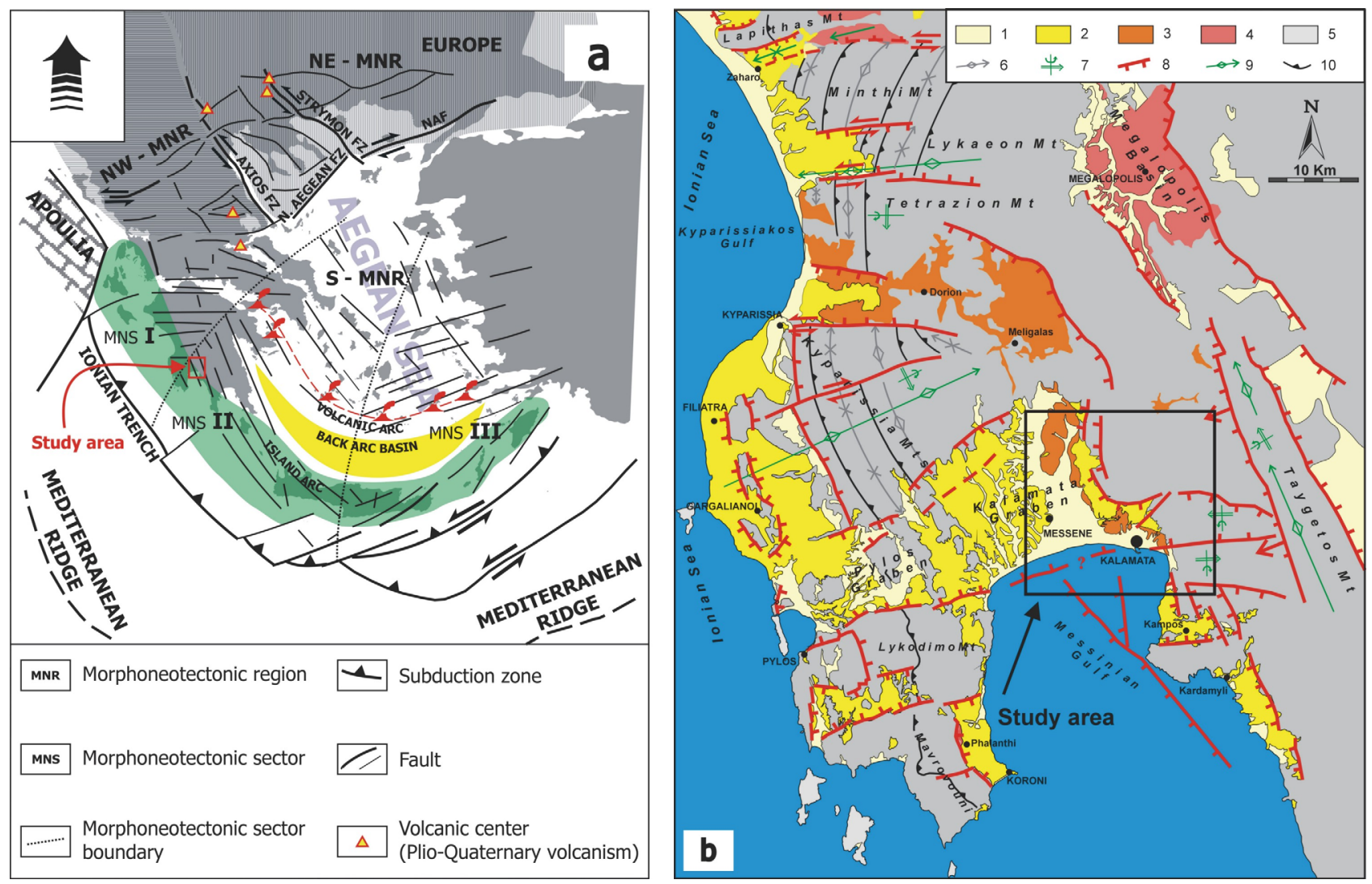

Figure 1. (a) The Hellenic Arc system and the location of the earthquake affected area (Kalamata, September 13, 1986) [Mariolakos and Fountoulis 2004]. (b) Schematic map showing the neotectonic regime of SW Peloponnese and the four neotectonic megastructures (1st order structures) in the wider study area: (i) the N-S striking Taygetos Mt mega-horst, (ii) the Kalamata-Kyparissia mega-graben striking N$\mathrm{S}$ in its southern part and E-W further to the north, (iii) the very complex morphotectonic megastructure of Kyparissia Mts-Lykodimo Mt striking N-S and considered as horst in comparison with the eastern Kalamata-Kyparissia mega-graben and as graben in comparison with the following Gargallianoi-Pylos mega-horst and (iv) the Gargallianoi-Pylos mega-horst occurred along the western coast of Messinia [Mariolakos et al. 1986, Mariolakos 1990]. Legend of Figure 1b: 1: Holocene deposits, 2: Late Pliocene-Early Pleistocene marine deposits, 3 : Plio-Pleistocene continental deposits, 4: Plio-Pleistocene lacustrine deposits, 5: Alpine basement, 6: Dominant plunge of alpine fold axes, 7: Rotational axis, 8: Neotectonic fault zone, 9: Neotectonic fold axis, 10: Thrust (modified from Fountoulis and Mariolakos [2008]; submarine faults from Papanikolaou et al. [1988] and Pavlakis et al. [1989]).

taceous and Eocene neritic carbonates and the Upper Eocene-Oligocene flysch formations and (d) the Pindos unit comprising thin-bedded, multi-folded pelagic limestones of Upper Cretaceous and clastic formations (the so-called "first flysch" formation of Jurassic-Lower Cretaceous age and the Danian-Eocene flysch). From the structural point of view, these four geotectonic units form a succession of three nappes. The slightly metamorphosed Mani unit is considered to be the relatively autochthonous one. The Arna unit (first nappe) overthrusts the Mani unit, the Tripolis unit (second nappe) overthrusts the Arna unit and the Pindos unit (third nappe) overthrusts the Tripolis unit (Figure 2).

\subsection{Post-alpine formations}

The post-alpine formations are classified into the Late Pliocene-Early Pleistocene marine sediments, the continental Middle-Late Pleistocene deposits and the Holocene deposits (Figures 1b, 2). The Late PlioceneEarly Pleistocene marine sediments comprise marls, sandstones and polymictic conglomerates [Marcopoulou-
Diacantoni et al. 1989, Mariolakos 1990, Mariolakos et al. 1993] depending on the paleogeographic evolution of the different sites and are observed mainly in grabens (Figure 2). Their current altitude is controlled by the local kinematic conditions since the Early Pleistocene [Marcopoulou-Diacantoni et al. 1989, Mariolakos 1990] when the uplift of the area started and continues today with these marine sediments currently observed at an altitude of about $460 \mathrm{~m}$ at the margins of the horsts (Figure 2). The total thickness of these sediments differs from sub basin to sub basin and is affected by the reactivations of the syn-sedimentary faults [Mariolakos et al. 1987].

The continental Middle-Late Pleistocene deposits consist mainly of red-colored, polymictic but always siliceous sands and conglomerates, the pebbles of which come exclusively from metamorphic rocks and/or radiolarites. They overlie unconformably the older formations and are deposited on a well formed palaeorelief, which is different from the recent one in its details [Mariolakos et al. 1986]. 

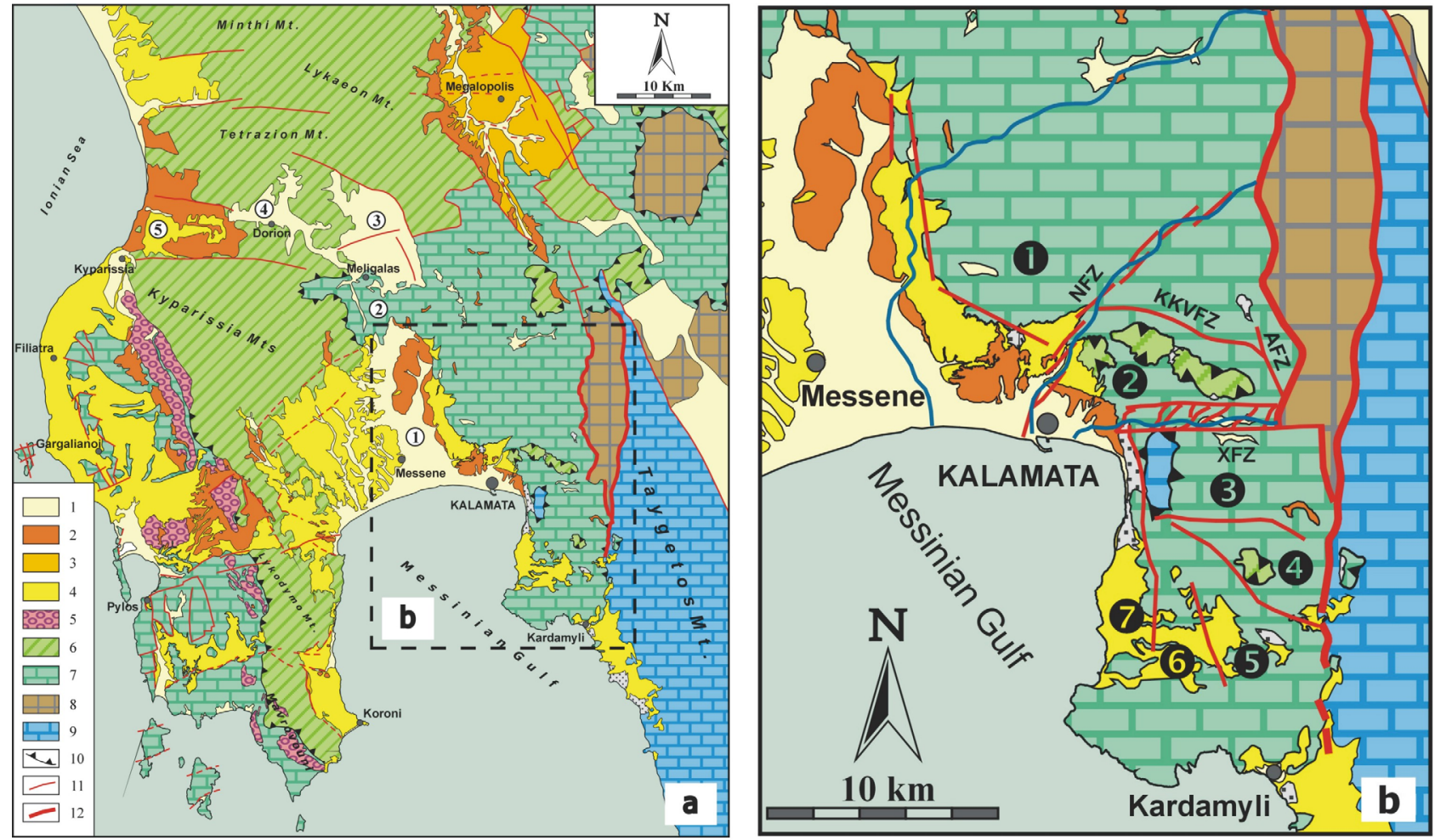

Figure 2. (a) Geological map of the SW Peloponnese 1: Holocene deposits, 2: Continental deposits, 3: Lacustrine deposits, 4: Marine deposits, 5: Conglomerates of Messinia (molasse), 6: Pindos Unit, 7: Gavrovo-Tripolis Unit, 8: Arna Unit (Phyllites - Quartzites), 9: Mani Unit, 10: Thrust, 11: Fault zone, 12: Detachment fault. The numbers in the white circles correspond to the following 2nd order neotectonic macrostructures within the 1st order Kalamata-Kyparissia mega-graben: 1: Kato Messinia graben, 2: Meligalas horst, 3: Ano Messinia graben, 4: Dorion basin, 5: Kyparissia-Kalo Nero graben. The area within the dashed line frame is presented magnified and more detailed in figure (b): the numbers in the black circles correspond to the following smaller order neotectonic macrostructures of the Kato Messinia graben: 1: AsprochomaKoutalas horst, 2: Dimiova-Perivolakia graben, 3: Kalathion Mt horst, 4: Altomyra semi-graben, 5: Kambos graben, 6: Vardia-Koka horst, 7: Kitries-Mantinia sub-graben, XFZ: Xerilas Fault zone, NFZ: Nedon Fault Zone, KKVFZ: Kato Karveli-Venitsa Fault Zone, AFZ: Arachova Fault Zone (after Mariolakos and Fountoulis [1988]).

Alluvial fans, unconsolidated or partly consolidated material, river deposits, fluvial terraces, talus cones and scree represent the Holocene [Mariolakos et al. 1986].

\section{Neotectonic structure of SW Peloponnese}

\subsection{Introduction}

The neotectonic structure of the SW Peloponnese is characterized by the presence of major neotectonic macrostructures including mega-horsts and megagrabens (1st order neotectonic macrostructures) bounded by N-S and E-W trending wide fault zones (Figures 1, 2) [Ladas et al. 2004, Mariolakos and Fountoulis 2004]. Block rotation differentiates the rates of uplift and subsidence throughout the margins of the neotectonic blocks and consequently the kinematic evolution of these structures is complex [Mariolakos et al. 1994, Ladas et al. 2004].

Smaller horsts and grabens (2nd order structures) are observed at the margins or within these 1st order neotectonic macrostructures of SW Peloponnese. The 2nd order structures strike either sub-parallel or perpendicular to the trend of the 1st order ones (Figures 1b, 2a). The integration of data from the detailed studies of sur- ficial geology and tectonics, drill cores for hydrogeological purposes and geoelectric data performed at some of these minor structures showed that these smaller (2nd order) structures are dynamically related, as they have resulted from the same stress field, but they are characterized by differences in their palaeogeographic, kinematic and geodynamic evolution that appeared either from the first stages of their creation, or later, during their evolution [Mariolakos et al. 1986, 1987].

\subsection{Neotectonic macrostructures of Messinia}

The Messinia area comprises four neotectonic mega-structures (1st order structures), which are the following from $\mathrm{E}$ to $\mathrm{W}$ : (i) the N-S striking Taygetos Mt mega-horst, (ii) the Kalamata-Kyparissia mega-graben striking N-S in its southern part and E-W further to the north, (iii) the very complex morphotectonic megastructure of Kyparissia Mts-Lykodimo Mt striking N-S and considered as horst in comparison with the eastern Kalamata-Kyparissia mega-graben and as graben in comparison with the following Gargallianoi-Pylos megahorst and (iv) the Gargallianoi-Pylos mega-horst occurred along the western coast of Messinia [Mariolakos et al. 1986, Mariolakos 1990] (Figures 1b, 2a). 
The study area extends in the western part of the Taygetos Mt mega-horst and in the southeastern part of the Kalamata-Kyparissia mega-graben.

\subsubsection{Taygetos Mt mega-horst}

The Taygetos Mt mega-horst comprises alpine formations of the Tripolis geotectonic unit [Aubouin et al. 1976, Jacobshagen et al. 1978] (Figure 2) and was initially uplifted and folded during the Paleocene Hellenide orogeny. The western half of this structure is dominated by the phyllitic-quartzite series (Arna unit), which consists of phyllites, schists and quartzites of Permian age [Jacobshagen et al. 1978]. Angelier et al. [1982] suggest that subduction and associated underplating along the Hellenic Trench during the MiddleLate Miocene is thought to have initiated a phase of continuous uplift throughout the Peloponnese [Angelier et al. 1982], with the Taygetos Mt mega-horst and the Sparta Basin experiencing up to $0.4 \mathrm{~mm} / \mathrm{yr}$ of vertical displacement [Le Pichon and Angelier 1981].

\subsubsection{Kalamata-Kyparissia mega-graben}

The Kalamata-Kyparissia mega-graben is composed of neotectonic structures of minor order (2nd order structures) that strike either sub-parallel or perpendicular to the trend of the 1st order one and form a zone of land of low altitude which connects the Messinian Gulf with the Kyparissia bay (Ionian Sea) [Mariolakos et al. 1986] (Figure 2a). These 2nd order structures from SE to NW are (i) the Kato Messinia basin (structure 1 in Figure 2a) with the Kalamata city located at its SE part, (ii) the Meligalas horst (structure 2 in Figure 2a) separating the Kato Messinia basin from that of Ano Messinia, (iii) the Ano Messinia basin (structure 3 in Figure 2a), which constitutes the northwards prolongation of the Kato Messinia basin, (iv) the Dorion basin (structure 4 in Figure 2a) and (v) the Kyparissia-Kalo Nero basin (structure 5 in Figure 2a) [Mariolakos et al. 1986].

The Kato Messinia basin is located north of the Messinian Gulf (structure 1 in Figure 2a) and it came into terrestrial conditions after the Lower Pleistocene. It is filled with a thick sequence of clastic sediments and particularly marls, sandstones and conglomerates, mainly marine with some intercalations of fresh water beds in depth (lignites). These sediments are surficial covered by a red siliceous clastic material of Middle and Upper Pleistocene age.

The Ano Messinia basin (structure 3 in Figure 2a) is a half graben, filled with a thick sequence of continental deposits. The thickness of the post-alpine sediments is larger than $280 \mathrm{~m}$ and consequently the alpine basement of the basin is around $180 \mathrm{~m}$ below the pres- ent sea level [Mariolakos 1988]. This fact in combination with the absence of marine deposits is a piece of evidence of the mobility of the graben and the sedimentary character of the younger tectonism.

The Dorion basin (structure 4 in Figure 2a) extends to the west of the Ano Messinia basin and it has been under erosional regime during the whole neotectonic period.

The E-W striking Kyparissia-Kalo Nero basin (structure 5 in Figure 2a) was a palaeobay of the Ionian Sea until the Lower Pleistocene. This palaeobay was separated from the palaeobay of the Kato Messinia during Pliocene and Lower Pleistocene by a low and relative narrow strip of land, which extended between Meligalas and Dorion. This area should be considered as a palaeo-isthmus.

\subsection{Neotectonic macrostructures of the meizoseismal} area

\subsubsection{Marginal fault zones and faults}

The meizoseismal area is located at the southeastern margin of the Kalamata-Kyparissia mega-graben (1st order structure) and constitutes the northwards prolongation of the Messinian Gulf (Figure 2). The Kalamata-Kyparissia mega-graben is limited between two major fault zones. The first fault zone defines the eastern and the northern margin of the basin and the second fault zone defines the western and the southern one (Figure 2).

In this paper, we focus on the southern part of the first fault zone that is observed in the meizoseismal area and which defines the eastern and northern margin of the mega-graben (Figure 2). It is significant to note that the strike of the partial faults is not stable along the margin and that the faults are not continuous but interrupted and intersected by others, which have different strikes, although they belong to the same fault zone. As a matter of fact, they build conjugate sets of faults which have been created during the same deformation phase [Mariolakos et al. 1986, 1987].

In the described marginal fault zone, the faults strike mainly NNW-SSE and WNW-ESE, but the dominant direction depends on the area (Figure 2). The "en echelon" arrangement of faults is another significant characteristic of this marginal fault zone (Figure 2). Therefore, the deformation, from the dynamic point of view, is not connected with an axial extensional stress field, but with coupling [Mariolakos et al. 1986, 1987].

Considering the Kalamata-Kyparissia mega-graben as the major neotectonic structure of the meizoseismal area, there are minor structures (2nd order structures) observed within as well as at its eastern and southern 
margins. Some of them are parallel to the higher order macrostructure whereas others are perpendicular to it and from NW to SE are the following (Figure 2b): (a) the Asprochoma-Koutalas horst (structure 1 in Figure $2 b$ ) in the north of the Kalamata city, (b) the E-W striking Dimiova-Perivolakia graben (structure 2 in Figure $2 \mathrm{~b}$ ), which rotates towards WSW around a N-S striking axis which is transverse to the Messinian Gulf, (c) the impressive E-W striking Kalathion Mt horst (structure 3 in Figure 2b), which rotates eastwards, forming the southern margin of the Dimiova-Perivolakia graben, (d) the Altomyra semi-graben (structure 4 in Figure 2b), at the southern slopes of Kalathion Mt, (e) the N-S striking Kambos graben (structure 5 in Figure 2b), (f) the N-S striking Vardia-Koka horst (structure 6 in Figure $2 \mathrm{~b}$ ) built up from the Vardia-Koka-Doloi hills and (g) the Kitries-Mantinia sub-graben (structure 7 in Figure 2b) [Mariolakos et al. 1986, 1993, Mariolakos and Fountoulis 1998].

\subsubsection{The Dimiova-Perivolakia graben}

The Dimiova-Perivolakia graben (structure 2 in Figure $2 \mathrm{~b}$ ) is the most important minor (2nd order) structural unit strongly related to and activated by the September 13, 1986, Kalamata earthquake, as most of the EEE were located therein and considerable structural damage occurred in the Elaeochori, Perivolakia, Kato Karveli and Diassello villages and the Kalamata city (Figure 3). The graben is bounded to the north by the NW-SE striking Kato Karveli-Venitsa fault zone (KKVFZ in Figure 2b), to the east by the N-S striking Arachova fault zone (AFZ in Figure 2b), to the south by the E-W striking Xerilas fault zone (XFZ in Figure $2 \mathrm{~b})$ and to the west by the NE-SW striking Nedon fault zone (NFZ in Figure $2 b$ ).

The study of the structural and geomorphological elements of this graben has proved that the endogenetic processes related to its creation and its evolution until present are very complex from both kinematic and dynamic viewpoints [Mariolakos et al. 1986, 1987, 1989]. Mariolakos et al. [1989] interpreted the kinematic regime of this macrostructure based on the integration of data derived from the study of active marginal faults, the structural contour map of the basement of the Pindos nappe and the geomorphological elements such as the planation surfaces and the river incision. They suggest that the graben is the result of rotational movements which took place around a N-S striking principal axis located at the area of Arachova and secondarily around an E-W striking axis located parallel to the Kato Karveli-Venitsa and Xerilas fault zones (Figure 2b), so that the western part of the graben is relatively the most subsiding area. These rotational movements have great influence on the relief, the morphology and mainly the distribution and the dip of planation surfaces, which dip towards the west.

\section{Seismic history of the wider Kalamata area}

The Kalamata area is located very close $(<70 \mathrm{~km})$ to the Hellenic (Ionian) Trench region, in which the subduction of the African plate beneath the European (Aegean) one takes place and thus it is one of the most seismically active areas of Greece [Mariolakos et al. 1987] (Figure 1a). Historical seismicity in SW Peloponnese before 1800 is very imperfectly known, but there is evidence that the Kato Messinia area was hit by a number of destructive earthquakes in the last 200 years (1846, June 10, $37.15 \mathrm{~N}, 22.00 \mathrm{E}, \mathrm{M}=6.6, \mathrm{X}$ in Messini; 1885, March 28, $37.10 \mathrm{~N}, 22.00 \mathrm{E}, \mathrm{M}=6.0$, VIII in Messini; 1926, September 19, 36.10 N, 22.10 E, M=6.3, V in Koroni; 1947, October 6, 36.96 N, 21.68 E, M=7.0, IX in Pylia; 1964, July 17, 38.00 N, 23.60 E, M=6.0, VI in Kinigos; 1986, September 13, 37.05 N, 22.11 E, $\mathrm{M}=6.0$, IX in Kalamata; 1997, October 13, 36.45 N, 22.16 E, M=6.4, VI+ in Koroni) [Papazachos and Papazachou 2003]. A strong correlation between earthquakes and certain branches of the fault zone defining the margins of the Kalamata-Kyparissia graben is evident, and is most likely indicative of reactivation of various segments of these fault zones in the last 200 years.

Local earthquakes have frequently affected this area. An example is the December 29, 1896, earthquake, which caused cracks in walls in the Kalamata city and the collapse of some buildings in the Elaeochori village. During the period 1893-1930, 65 earthquakes were reported only from the Kalamata area and they were related to local sources and not associated with the Hellenic (Ionian) Trench region [Elnashai and Pilakoutas 1986]. The 1947 event was probably responsible for liquefaction phenomena along the Kalamata coast [Papazachos and Papazachou 2003]. The most recent events, which hit this area, are the September 13, 1986, Kalamata earthquake discussed herein and a moderate earthquake $(M L=5.0)$ generated in the vicinity of the Kalamata city on March 1, 2004.

\section{The September 1986 Kalamata earthquake se- quence}

On September 13, 1986, a shallow depth $(<10 \mathrm{~km})$ earthquake struck the Kalamata city and the surrounding areas resulting in 20 fatalities, over 300 injuries, extensive structural damage and many EEE. The epicenter of the main earthquake was located about $10 \mathrm{~km}$ NNE of the Kalamata city and its magnitude was $\mathrm{Ms}=6.2$ [Papazachos et al. 1988] (Figure 3). The focal mechanism of the main shock shows an E-W extension [Lyon- 


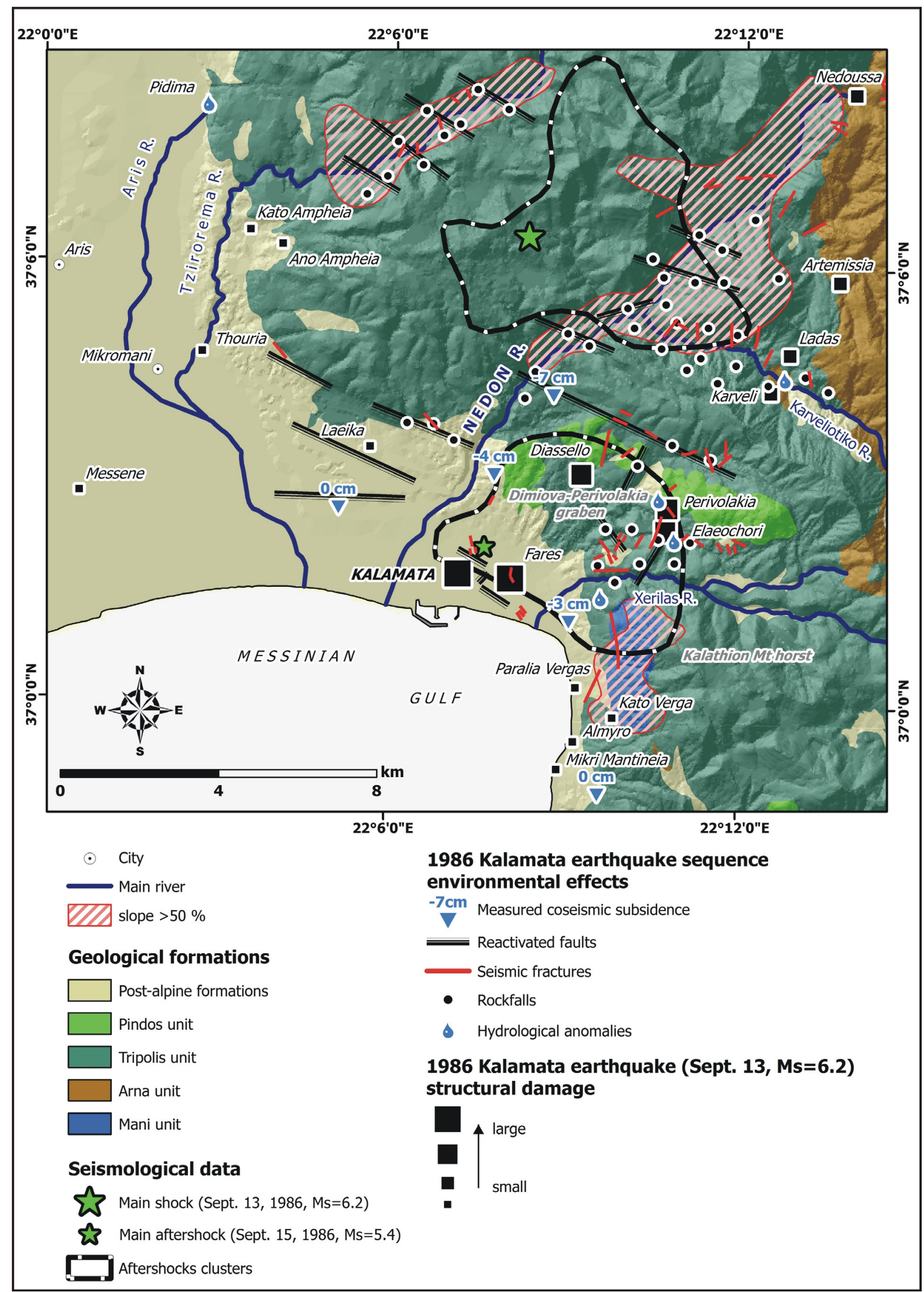

Figure 3. The spatial distribution of the environmental effects induced by the September 1986 Kalamata earthquake sequence and the structural damage caused by the September 13 Kalamata earthquake based on data from Mariolakos et al. [1986, 1987, 1989, 1992], Fountoulis and Grivas [1988], Papazachos et al. [1988], Tselentis et al. [1988], Gazetas et al. [1990], Mariolakos and Fountoulis [1998], Fountoulis [2004] and Stiros and Kontogianni [2008]. It is significant to note that the EEE observed around the Tzirorema gorge (NE-SW trending part of Tzirorema River in the northern part of the map) were induced by the strongest aftershock occurred two days later (September 15, 1986, Ms=5.4). 
Caen et al. 1988, Papazachos et al. 1988]. Less than 48 hours later, an aftershock of Ms $=5.4$ occurred closer to the Kalamata city (Figure 3 ) at the same depth $[\mathrm{Pa}$ pazachos et al. 1988].

Seismological studies of Papazachos et al. [1988] and Lyon-Caen et al. [1988] indicated that the aftershocks defined two clusters (Figure 3 ) and an about 45 degrees west-dipping fault plane. The foci depths of the seismic sequence were ranging between 11 and $0.9 \mathrm{~km}$, while the majority of their focal mechanisms indicated extension in $\mathrm{E}-\mathrm{W}$ direction. This deformation pattern is consistent with the focal mechanism of the main shock derived from first motion arrivals indicating a nearly $\mathrm{N}$ $S$ striking, west-dipping normal fault [Lyon-Caen et al. 1988, Papazachos et al. 1988].

Tselentis et al. [1988] concluded that the area is tectonically very complex based on the variety of orientations and dips calculated for the sub-faults activated during the aftershock sequence. The analysis of the northern cluster indicates the existence of two types of orientation, which are dipping in four different angles and the southern cluster is characterized by an almost uniform behavior activated later in the sequence. This conclusion is in agreement with the neotectonic structure described by Mariolakos et al. [1986, 1987, 1989, 1992, 1993] and Mariolakos and Fountoulis [1998].

The September 13, 1986, Kalamata earthquake produced a maximum intensity VIII+ on the IMM or EMS 1992 scale [Elnashai et al. 1987, Gazetas et al. 1990], while Leventakis et al. [1992] presented an equalintensity contour map for the Kalamata city due to the September 13, 1986, earthquake and estimated the intensity up to IX-X.

\section{Spatial distribution of the 1986 Kalamata earth- quake sequence environmental effects and ESI 2007 intensities for the September 13, 1986, Kalamata earthquake}

During the above-mentioned seismic activity, coseismic subsidence, reactivation of faults (seismic faults), seismic fractures, slope movements including rockfalls and hydrological anomalies were observed [Elnashai and Pilakoutas 1986, Mariolakos et al. 1986, 1987, 1989, Fountoulis and Grivas 1989, Mariolakos and Fountoulis 1998, Fountoulis 2004, Stiros and Kontogianni 2008] covering a total area of about $200 \mathrm{~km}^{2}$ (Figure 3). Based on this total area, the ESI 2007 epicentral intensity degree is VIII-IX and closer to VIII.

\subsection{Subsidence}

Stiros and Kontogianni [2008] applied two firstorder leveling traverses crossing the wider Kalamata area. The computed displacement signal along the two traverses is quite different. Along the western branch this signal is very small, less than $1 \mathrm{~cm}$, and not statistically significant at the $95 \%$ confidence level [Stiros and Kontogianni 2008]. On the contrary, along the eastern branch, a $7 \mathrm{~cm}$ relative height difference between the tips was obtained $(-7 \mathrm{~cm}$ in Figure 3). The corresponding displacement signal has a systematic pattern (is increasing nearly gradually) and is significant at the $95 \%$ confidence level [Stiros and Kontogianni 2008]. They concluded that levelling data covering the period from 1963 to $1986 / 87$ suggests that a small but statistically significant subsidence occurred in the area east and north-east of Kalamata, while no significant vertical movements were observed west and southeast of the city $(0 \mathrm{~cm}$ west and southeast of Kalamata in Figure 3$)$. The observed elevation changes are attributed to the September 13, 1986, Kalamata earthquake due to the fact that this earthquake was the only significant event which could have produced such a vertical crustal deformation during the study period (1963-1987) in the wider Kalamata area [Stiros and Kontogianni 2008].

Considering the above mentioned data, it is concluded that the measured subsidence ranged from 3 to 7 $\mathrm{cm}$ in the area east of Kalamata (Figure 3). Therefore, a $\mathrm{VII}_{\mathrm{ESI}} 2007$ intensity was assigned for this area (Figure 4).

\subsection{Seismic faults}

As seismic faults are characterized the seismic fractures which present an obvious slip [Mariolakos et al. 1986, 1987]. Actually, seismic faults are reactivated parts of an older fault [Mariolakos et al. 1986, 1987]. The following information about the seismic faults were presented and described by Mariolakos et al. [1986, 1987, 1989], Mariolakos and Fountoulis [1998] and Fountoulis [2004].

Seismic faults have been observed in the Tripolis carbonates, in the Pindos pelagic formations and in the Neogene formations (Figures 3, 5a,b). No reactivation was observed in the other geological formations of the study area (Tripolis flysch and the Quaternary deposits) (Figure 3). In areas with intense relief, all reactivations of faults were accompanied by rockfalls (Figure 3).

Reactivation of faults was observed in: (a) the Elaeochori area (Figure 5a,b), where the active E-W striking Xerilas fault zone (XFZ) occurs, (b) in the area of the Kato Karveli village, where the active NW-SE striking Kato Karveli-Venitsa fault zone (KKVFZ) occur, (c) in the area north of the Kato Karveli village, where the active NE-SW striking Nedon fault zone (NFZ) occurs, (d) in the area of the Asprochoma village located west of the active Nedon fault zone (NFZ), (e) in the area east of the Laeika village and east of the Thouria village, where a NW-SE striking active fault 


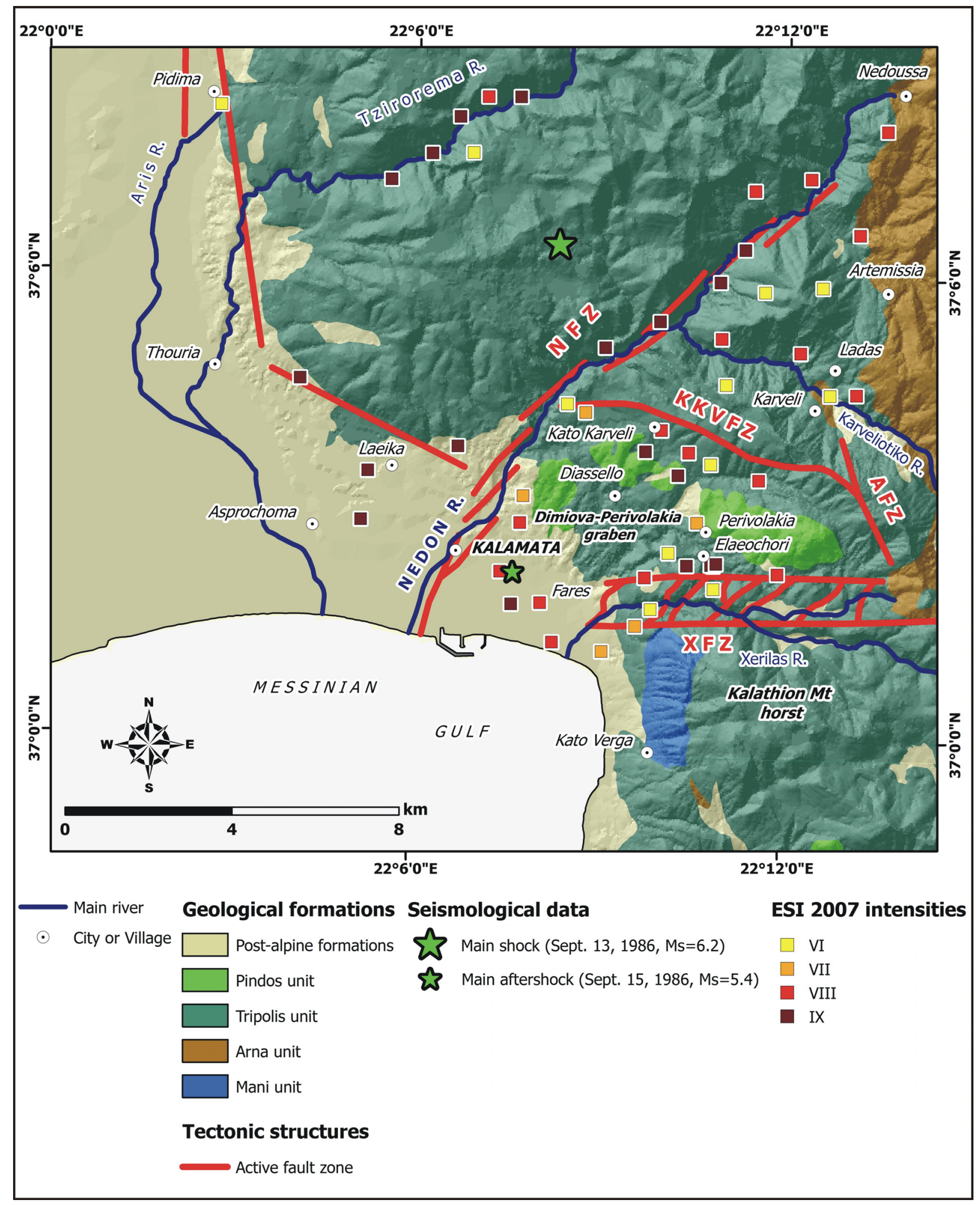

Figure 4. Geological map with the seismic intensities derived from the application of the ESI 2007 scale to the September 13, 1986, Kalamata earthquake and their correlation with the neotectonic macrostructures (the Dimiova-Perivolakia graben and the Kalathion Mt horst) and the active fault zones of the study area (NFZ: Nedon fault zone, KKVFZ: Kato Karveli-Venitsa fault zone, AFZ: Arachova fault zone, XFZ: Xerilas fault zone). The ESI 2007 values derived from the use of EEE induced by the strongest aftershock around Tzirorema gorge (NE-SW trending part of Tzirorema River in the northern part of the map) are also presented here.

zone is observed and finally (f) in the Tzirorema gorge developed along the NE-SW trending part of Tzirorema River located north of the damage area (Figure 3). It is significant to note that a totally new fault was created on the uppermost tectonic unit (Pindos unit) in the area of the small village Diassello.

In some places, as for example in the Elaeochori village, reactivation of faults has taken place both during the main shock and the aftershock, while in others, as in Tzirorema gorge located north of the damage area (Fig- 
ure 3), a reactivation of a fault occurred only during the aftershock [Mariolakos et al. 1986, 1989, Fountoulis 2004].

Reactivated faults strike in different directions (NS, E-W, NNE-SSW, NW-SE, NE-SW). The throw of the normal faults due to the reactivation ranged from 10 to $20 \mathrm{~cm}$. Considering these data, an IX $\mathrm{ESI} 2007_{\text {intensity }}$ was assigned to the locations where seismic faults were observed during the September 13, 1986, Kalamata earthquake (Figure 4).

\subsection{Seismic fractures}

Contrary to the seismic faults, seismic fractures do not present an obvious slip [Mariolakos et al. 1986, 1987]. Seismic fractures presented and described thoroughly by Mariolakos et al. [1986, 1989] and Fountoulis [2004] have been observed in many places and in almost every geological formation (alpine and post-alpine) (Figure 3). Most of them were relatively small (3-5 m long), whereas some of them were very large (10-50 m long). They presented a vertical displacement of several $\mathrm{mm}$ up to $25-30 \mathrm{~cm}$ [Mariolakos et al. 1986, 1989] and they often presented a horizontal component showing sinistral or dextral displacement [Mariolakos et al. 1986, 1989, Fountoulis and Grivas 1989].

Seismic fractures also form a zone or zones of smaller ones with their width ranging from 2 to $5 \mathrm{~m}$. The density of the fracture zones containing large fractures varied from place to place. In one case, the fracture density was measured as ten fracture zones per 100 $\mathrm{m}$ [Mariolakos et al. 1986]. The arrangement of the seismic fractures inside a zone was typical en echelon.

The seismic fractures are not planar, so their shape on the ground is not a straight but a crooked line. The set consisting of the greater fractures is of first order, whereas the set which consists of the smaller fractures is of second order (Figure 3). In some places, the firstorder set became secondary and vice-versa.

Based on the aforementioned fracture dimensions (fractures with length ranging from 3 to $50 \mathrm{~m}$, maximum width about $15 \mathrm{~cm}$, vertical displacement of several $\mathrm{mm}$ up to $25-30 \mathrm{~cm}$, zones of seismic fractures with length ranging from $150 \mathrm{~m}$ to $1.5 \mathrm{~km}$ and width ranging from 2 to 5 m) [Mariolakos et al. 1986, 1987, 1989, Fountoulis and Grivas 1989, Fountoulis 2004] and the ESI 2007 guidelines [Michetti et al. 2007], a VIII ${ }_{\text {ESI } 2007}$ intensity was assigned to the majority of seismic fractures (Figure 4).

\subsection{Rockfalls}

As it is known, rockfalls are theoretically linked to the decrease of the coherence and the angle of internal friction and to the increase of the slope gradient, while practically they depend on the number of tec- tonic discontinuities within a rock body and on the angular relationship between tectonic discontinuities surfaces and the slope dip [Mariolakos 1991]. However, the rockfalls induced in the greater area of Kalamata during the seismic activity of September 1986 are differentiated from the above mentioned. This is because rockfalls were also observed in sections of the area in which the conditions did not support their initiation; while in sections where suitable conditions already existed at that time, rockfalls did not occur.

The majority of rockfalls were observed in several sections along the steep slopes of the Tzirorema, Karveliotiko and Xerilas streams, the Nedon River as well as in the greater area of the Elaeochori, Karveli and Ladas villages [Mariolakos et al. 1986, 1992, Fountoulis 2004] (Figures 3, 5e,f). Rockfalls were observed during the main shock (September 13, 1986) and during the strongest aftershock (September 15, 1986), for example in the greater area of Elaeochori, Karveli and Ladas villages (Figure 3) and so on, while in other areas rockfalls were observed only during the strongest aftershock (September 15, 1986), for example in the area of Tzirorema [Mariolakos et al. 1986, 1992, Fountoulis 2004] (Figure 3).

The largest percentage of rockfalls was observed in areas where the average morphological slope is greater than 50 percent. But this is not the rule as rockfalls were also observed in areas, where the average morphological slope was less than 50 percent (Figure 3 ). It is worth mentioning that movement or even overturning of relatively large blocks was observed in isolated cases (e.g. a limestone block with dimensions $60 \times 40 \times 30 \mathrm{~cm}$ ), even in nearly horizontal relief with morphological dip ranging from 0 to 10 percent. This was observed in the greater area of Elaeochori and more specifically by the side of the road from Kalamata to Elaeochori consisting of Tripolis limestones [Mariolakos et al. 1986].

From field observations made on the southeastern slope of the Tzirorema stream, it can be said that the geographical distribution of rockfalls can be related to the fracture frequency in the fractured zones and to the normal fault zones, which were reactivated in the area in a NW direction [Mariolakos et al. 1992]. It is important to note that at the northern side of the Tzirorema gorge, although suitable conditions already existed (similarly inclined beds and slopes etc.), rockfalls were significantly few. Rockfalls observed along the slopes of the Xerilas stream were triggered by the seismic fractures of the area, which were the main reason of fracturing and fragmentation of the rocks.

It is significant that no rockfalls were generated along the Kalathion Mt horst (Figure 3), despite the fact that suitable conditions prevail in the scree and along 

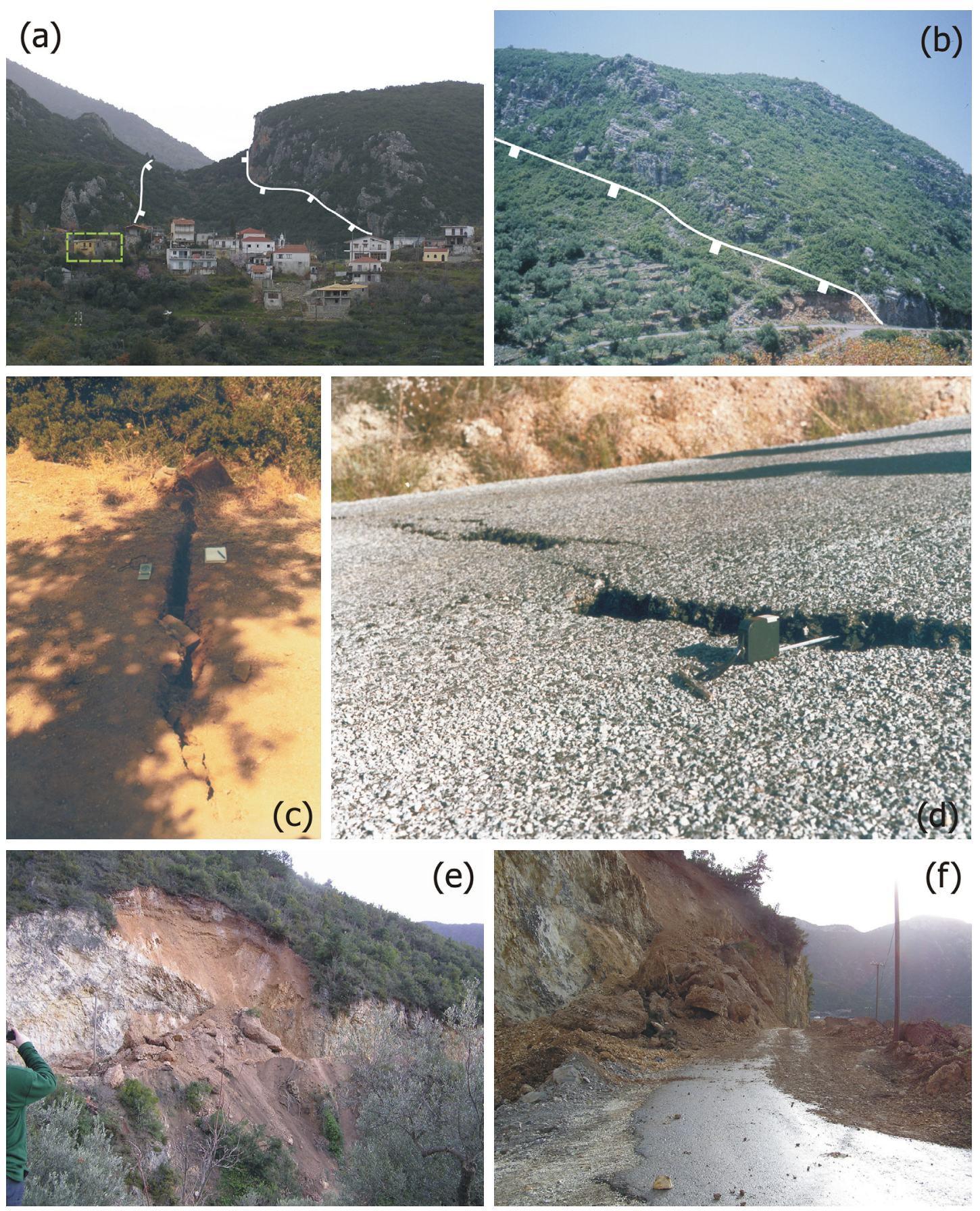

Figure 5. Earthquake environmental effects induced by the September 13, 1986, Kalamata earthquake. (a) Panoramic view of the Elaeochori village. The two untouched old houses in the almost total destroyed Elaeochori village are still standing in the western part of the village (in the green dashed frame). Faults are observed in the western (right) and the eastern (left) part of the photo forming a graben (ticks on the hanging-wall block). (b) Fault reactivated by the September 13, 1986, Kalamata earthquake in the eastern part of the village (ticks on the hanging-wall block). (c) Seismic fractures with $2 \mathrm{~m}$ length, $15 \mathrm{~cm}$ width and depth of over $1 \mathrm{~m}$ and (d) seismic fractures with $3 \mathrm{~m}$ length, $10 \mathrm{~cm}$ width and depth of over $1 \mathrm{~m}$ observed in the activated Dimiova-Perivolakia graben $(e, f)$ Landslides induced in the area of the Ladas village.

the steep slopes. According to Mariolakos et al. [1986] and Fountoulis [2004], this fact is related to the lack of reactivation of fault zones in the area. Therefore, Mariolakos et al. [1986] made use of the terms "seismic rockfalls" and "seismic scree", depending on the size of the material.

Nearly everywhere the rockfalls were related to the reactivation of active faults and the presence of tectonic zones causing reduction of rock consistency.
Therefore, the intense relief and the geometry of tectonic discontinuities acted only supplementary to the generation of rockfalls.

Based on the aforementioned rockfalls data [Mariolakos et al. 1986, 1992, Fountoulis and Grivas 1989, Fountoulis 2004] and the ESI 2007 guidelines [Michetti et al. 2007], a VI $\mathrm{ESI}_{2007}$ intensity was assigned to rockfalls because of their volume, which was smaller than $10^{3} \mathrm{~m}^{3}$ (Figure 4). 


\subsection{Hydrological anomalies}

For a few hours after the main shock turbidity was reported in the water of the springs that are located north of Kalamata and supply the city with water (Aris River source located in the Pidima village, Figure 3 ) as well as in the spring water from the Karveli village [Elnashai and Pilakoutas 1986] (Figure 3). Therefore, the assigned intensity for this region is $\mathrm{VI}_{\mathrm{ESI} 2007}$ (Figure 4).

Springs in the Elaeochori village and in places higher up showed increased yield, while springs lower down the mountain side dried up (Figure 3) [Elnashai and Pilakoutas 1986]. At the Perivolakia village, the spring located on the contact between limestones and flysh (Figure 3), stopped flowing for two hours after the earthquake and began to flow again with increased discharge. Therefore, the estimated intensity for the Elaeochori and the Perivolakia villages and the area ex-

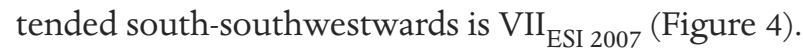

\subsection{Liquefaction}

At the time of the earthquake the ground water in Kalamata was at its lowest annual level. The short duration of the shock and the low number of load cycles to which the soil was subjected was insufficient for any significant pore-water pressure build-up and hence no changes in the ground level or any signs of ground failures induced by liquefaction was reported or seen [Elnashai and Pilakoutas 1986].

For the same meizoseismal area of the June 10, 1846, earthquake, Galanopoulos [1947] reported that "near the village of Mpaliaga [located north of the Messini town and west of Aris River] soil ruptures were observed from which water and sand were released forming a small lake. Near the Mikromani village [Figure 3] soil ruptures were observed that had a width of nearly $3-5 \mathrm{~cm}$ with sand cones that had a width of nearly $10 \mathrm{~cm}$. From the openings of these cones, fluid materials were released. Next to the banks of the river Pamissos the ruptures were of greater width and partly filled by mud...". From this description it can be concluded that the observed phenomenon was liquefaction, something that was not recorded during the September 13, 1986, Kalamata earthquake [Mariolakos et al. 1986, Fountoulis 2004].

\section{Structures, structural damage and EMS-98 intensi-} ties for the September 13, 1986, Kalamata earthquake

\subsection{Types of structures}

Gazetas et al. [1990] studied the local-soil and source-mechanism effects in the 1986 Kalamata earthquake, focused on the distribution of damage within the Kalamata city and came up with the following con- clusions for the dominant structural types observed in the city and the surrounding areas:

(i) The first dominant type of structures includes three- to seven-storey reinforced-concrete (R/C) frameand-shear-wall buildings with thick brick partition walls presented in all but the ground floor, which is left open for various uses. These buildings were constructed according to the Greek Seismic Code that was implemented in 1959 with subsequent revisions and upgrades. Much of the heavy damage to such buildings included failure of the ground floor columns [Anagnostopoulos et al. 1987, Fardis 1987, Elnashai et al. 1988]. This type of damage was attributed to the combination of the discontinuity in the vertical direction with the inadvertently resulting "weak-column strongbeam" design proved to be extremely vulnerable to ground shaking [Anagnostopoulos et al. 1987, Fardis 1987, Elnashai et al. 1988].

(ii) The second dominant structural type includes one- to three-storey brick or stone masonry bearing wall buildings built mainly before the first Greek Seismic Code. They experienced severe damage, depending mainly on their construction quality.

\subsection{Structural damage, EMS-98 intensities and factors} affecting the damage distribution

Based on Grünthal [1998], EMS-98 intensities were assigned to each of the localities damaged by the earthquake and an intensity map was constructed based on the EMS-98 intensities depicting the spatial distribution of the damage (Figure 6).

The maximum EMS-98 intensity obtained for the earthquake affected area is IX $\mathrm{EMS}_{\mathrm{Eg}}$ and is assigned to the Kalamata city and the Elaeochori and the Kato Karveli villages (Figure 6). In the Kalamata city, three 5 -storey buildings and one 4-storey collapsed (Figure 7). Out of a total of 9124 buildings, 20 percent were demolished, 16 percent underwent serious damage, 36 percent suffered minor damage and only 28 percent suffered no damage at all (http:/ / www.oasp.gr/node / 672).

The geological basement on which the various constructions were founded varies. Kalamata has a basement that is composed of coastal, loose riverbed deposits (gravel, sand, clay etc.), or red siliceous clastic formations that are relatively more consolidated than those previously mentioned, or marls, sandstones, conglomerates, sediments even more consolidated than those previously mentioned, of Pliocene-Pleistocene age, or even alpine basement [Mariolakos et al. 1986].

Low-rise and stiff structures suffered the most in the Kalamata suburb of Fares (Giannitsanika) (IX $\left.\mathrm{EMS}_{-98}\right)$ (Figure 6), where 80 percent of the structures experienced significant damage, i.e. they collapsed during the 


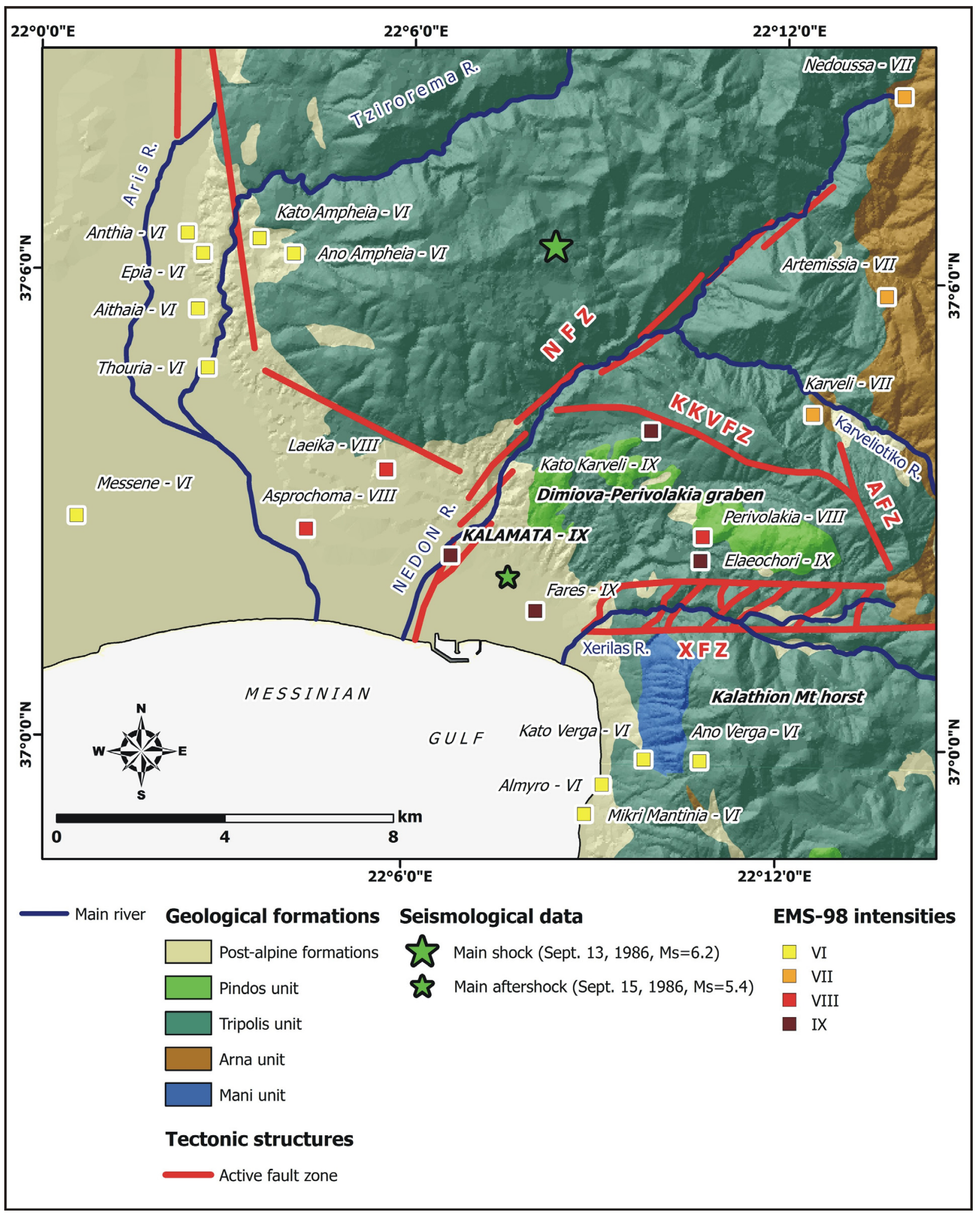

Figure 6. Geological map depicting the seismic intensities derived from the application of the EMS-98 scale to the September 13, 1986, Kalamata earthquake and their correlation with the neotectonic structures and the active fault zones of the study area (NFZ: Nedon fault zone, KKVFZ: Kato Karveli-Venitsa fault zone, AFZ: Arachova fault zone, XFZ: Xerilas fault zone).

earthquake, or were demolished afterwards, or required extensive post-earthquake structural repairs [Elnashai and Pilakoutas 1986, Gazetas et al. 1990]. Almost equally extensive was the damage in the old town (75 percent) and slightly less in the central part of the city (60 percent) [Elnashai and Pilakoutas 1986, Gazetas et al. 1990]. However, only 15 percent of the buildings were damaged in the coastal area near the harbor and an even smaller percentage in the thinly populated coast west of the Nedon River bed [Elnashai and Pilakoutas 1986, Gazetas et al. 1990].

The pattern of damage distribution among 22 churches (several of which were a few centuries old) is fairly consistent with that in the stiff buildings. Thus, 
two of the three contemporary churches in Giannitsanika collapsed; old and new churches in the old town were either very seriously damaged or partially collapsed, while only a few easily repairable cracks in the bell-towers were observed in the three churches of the coastal area [Gazetas et al. 1990].

The Elaeochori village (IX $\mathrm{EMS}_{\text {-98 }}$ ) (Figure 6), located further east of Kalamata, was one of the most damaged villages, as almost all buildings were collapsed or suffered severe damage. It is founded on the marginal fault zone (Xerilas fault zone; XFZ) between the Kalathion Mt horst to the south and the Dimiova-Perivolakia graben to the north (Figures 4, 5). A number of parallel E-W striking big faults in en echelon arrangement constitute the fault zone (Figure 4). It is a typical scissor fault zone and the vertical throw is zero at its eastern part and increases towards west. At the western part of the fault zone the total throw is more than $2000 \mathrm{~m}$ [Mariolakos et al. 1986, 1989]. Almost all buildings were founded on the thick-bedded or non-bedded neritic Cretaceous-Eocene carbonates of Tripolis unit, the thickness of which is more than $1000 \mathrm{~m}$ [Mariolakos et al. 1986].

Out of a total of 120 buildings of the Elaeochori village, only three were untouched by the earthquake while two of them were among the oldest buildings of the village. These buildings are the best example to study the crucial role of the reactivation of specific faults and/or fractures on the damage distribution. Both have been built on an E-W striking fault surface, which constitutes the contact between the neritic carbonates and the flysch sediments of the Tripolis unit (Figures 5a, $7 \mathrm{~d})$. This fact is very impressive and can be explained if somebody takes into account the type of the fault surface, as it is a typical alpine inactive fault surface and the buildings have been founded on the solid rock mass. So, despite the fact that (a) the two buildings were among the oldest ones, and (b) the morphological slope in this site is relatively steep, none of these buildings suffered any damage (Figure 7). Thus, Mariolakos and Fountoulis [1998] pointed out that damage in the Elaeochori was mainly due to fault and fracture reactivation as well as to the creation of new features. These faults and fractures were the main active factors for causing damage, contrary to other ones (inactive discontinuities, steep slopes, etc.), which played a secondary passive role. The density, the geometrical and kinematic characteristics of these active tectonic discontinuities defined the behavior of the rock-mass during this earthquake.

In the Kato Karveli village ( $\mathrm{IX}_{\mathrm{EMS}-98}$ ) (Figure 6) located $6 \mathrm{~km}$ northeast of the Kalamata city, out of 44 masonry buildings, 20 collapsed and the others were damaged.
A VIII ${ }_{\text {EMS-98 }}$ value is assigned to the Laeika, Asprochoma and Perivolakia villages (Figure 6). The Laeika village is located $3 \mathrm{~km}$ northwest of the Kalamata city (Figure 6). Most of the old masonry buildings suffered damage and the R/C buildings suffered nonstructural damage. In the Asprochoma village located 3 $\mathrm{km}$ west of the Kalamata, R/C and masonry buildings suffered moderate non-structural damage. The Perivolakia village is located about $6 \mathrm{~km}$ east of the Kalamata (Figure 6). Out of 65 masonry buildings, 15 to 20 were heavily damaged, while no damage was observed to the only five $\mathrm{R} / \mathrm{C}$ buildings, which were habitable.

The Karveli village is located $10 \mathrm{~km}$ northeast of the Kalamata city (Figure 6). Out of 114 mostly old masonry buildings, 3 collapsed. A VII ${ }_{\mathrm{EMS}-98}$ value is assigned to the Karveli village (Figure 6).

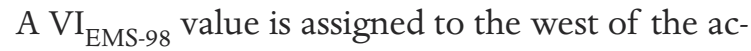
tive Nedon fault zone (NFZ) (Figure 6), where Messene, Ano Ampheia, Kato Ampheia, Epia, Anthia and Aithaia villages occur, and to the south of the active Xerilas fault zone (XFZ), where Kato Verga, Almyro, Mantinia and Ano Verga villages occur (Figure 6). In Messene, some cracks were observed in masonry buildings, while no damage was observed to the $\mathrm{R} / \mathrm{C}$ buildings. In the Ano Ampheia, Kato Ampheia, Epia, Anthia and Aithaia villages located 8-12 km northwest of Kalamata, some cracks were observed on few corners of masonry buildings, but no damage to $\mathrm{R} / \mathrm{C}$ buildings. In Kato and Ano Verga located 6-8 km southeast of Kalamata, old masonry buildings suffered damage but no damage to $\mathrm{R} / \mathrm{C}$ buildings was reported at all.

In the Nedoussa village ( $\mathrm{VII}_{\mathrm{EMS}-98}$ ) (Figure 6), located $16 \mathrm{~km}$ northeast of Kamalata, few collapses and heavy damage occurred in old masonry and adobe buildings. Some chimneys had been knocked off. The church and the Mardaki monastery were destroyed.

It is worth mentioning that during the earthquakes of 1944, damage was recorded in the Kato Verga, the Ano Verga and the Kambos villages, while no damage was recorded in the Kalamata city and the Elaeochori village [Papazachos and Papazachou 2003]. Similar conditions have been observed during past earthquakes. The earthquake that took place on June 10, 1846, which was of great macroseismic intensity and was felt in Asia Minor, destroyed many villages in Messinia and especially Messene, Mikromani and Aris among others located west of the Nedon River (Figure 3), while in Kalamata only a few houses collapsed [Galanopoulos 1947].

From field observations that have taken place, it seems that damage was not determined only from the age, type, height and other characteristics of the buildings. For example, there were cases where of two nearly identical constructions in the same area, one re- 

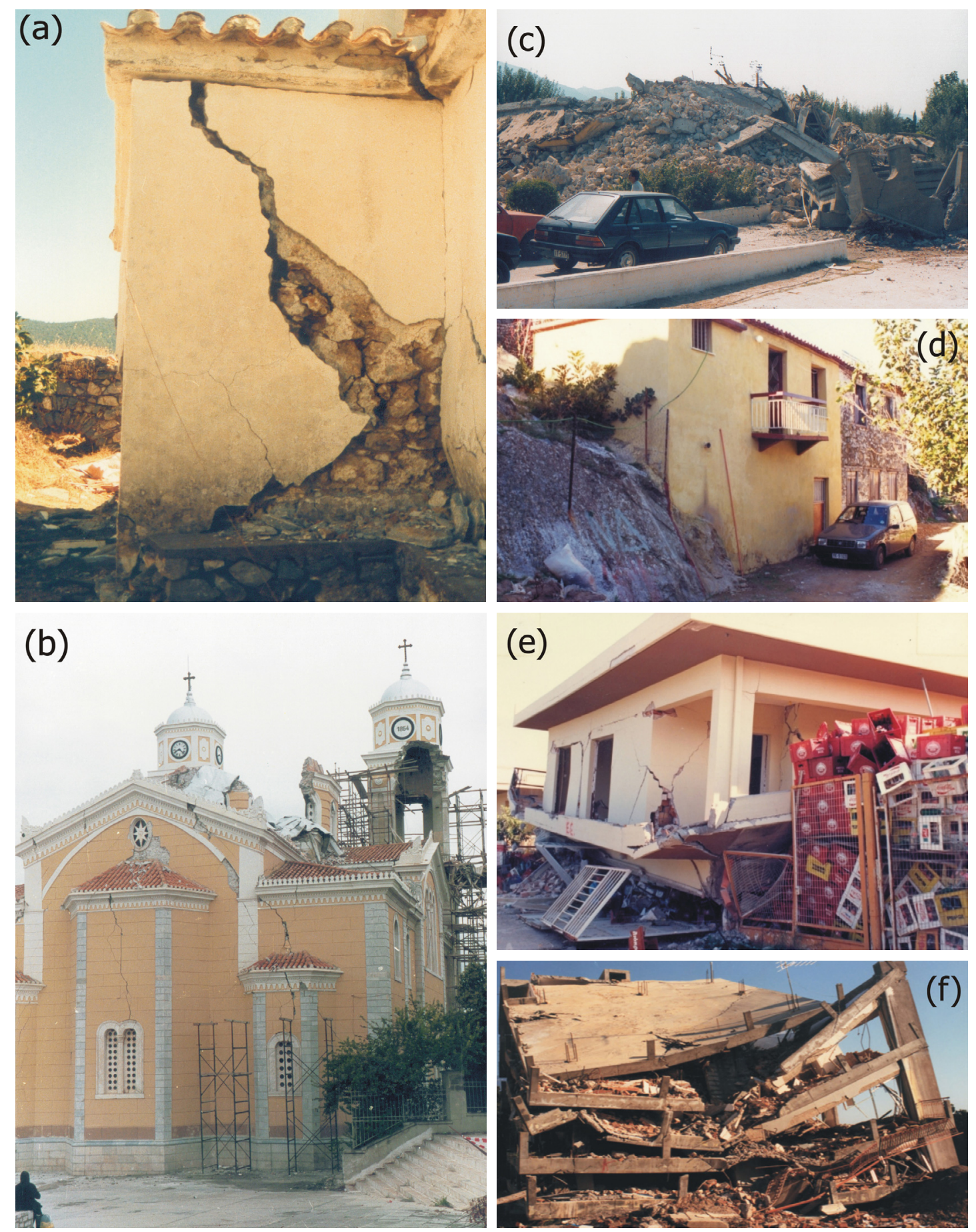

Figure 7. Characteristic structural damage caused by the September 13, 1986, Kalamata earthquake. The earthquake caused considerable damage to stone masonry buildings and churches including cracking (a, b), partial collapse of walls or total collapse of the building (c - masonry church in the Kalamata city). (d) Two old houses in the almost total destroyed Elaeochori village remained untouched by the earthquake. They have been built on an old E-W striking inactive fault surface forming the contact of the neritic carbonates and the flysch sediments of the Tripolis unit, but on a solid rock mass (neritic carbonates). (e, f) Multi-storey R/C buildings in Kalamata ( $\mathrm{IX}_{\mathrm{EMS}-98}$ ) suffered considerable damage and four of them collapsed.

mained intact while the other was destroyed.

During the September 1986 Kalamata seismic activity, old constructions such as the historical monastery of Mardaki near the Nedoussa village, which dated back to the 18th century, and the monastery of Velanidia north of Kalamata were nearly destroyed. Of course there is no detailed data for damage that previous earthquakes have caused to historical buildings and as a re- sult it is not possible to extract relevant conclusions.

In many other cases the building destruction was attributed to zones of seismic fracturing that were observed in the construction basement. Of course, this was not the rule. For example, no surface fracturing was observed in the area of the old Municipality Flea Market of the Kalamata city, where the main and surrounding buildings were damaged or destroyed (e.g. the temple 
of Agioi Apostoloi). On the other hand, in the Fares (Giannitsanika) area, where surface fracturing was observed, damage also occurred, while where no surface fracturing existed no damage occurred. Furthermore, at the Kalamata beach, the damage was minor in spite of the poor founding conditions (loose gravel, sand, high water table). However, exceptions still exist. Seismic fracturing must have been created during previous earthquakes in areas where damage occurred, but they were not recorded except in special cases such as the above mentioned earthquake of the June 10, 1846.

\section{Discussion and conclusions}

The effects induced by the September 13, 1986, Kalamata earthquake on the natural environment are characterized as a widespread source of considerable hazard and become important for seismic intensity assessment.

The small (of the order of a few $\mathrm{cm}$ ) but statistically significant subsidence of the area east and northeast of the Kalamata city derived from first-order leveling traverses [Stiros and Kontogianni 2008] is associated with the September 13, 1986, Kalamata earthquake, since this earthquake was the only significant event, which could have produced such a vertical crustal deformation in the study area. Moreover, other reasons responsible for vertical crustal deformation in an earthquake affected area, such as coastal subsidence or uplift, contamination of computed height differences by systematic, mainly refraction, errors and local ground subsidence or consolidation of recent sediments, were rejected [Stiros and Kontogianni 2008].

The seismic faults were strongly related to the active fault zones of the study area. They were created along the active Xerilas, Nedon, Kato Karveli-Venitsa and Arachova fault zones that bound the activated Dimiova-Perivolakia graben. The observed seismic fractures were induced by the ground shaking. They were not directly linked to the earthquake energy and in particular to the surface expression of the seismogenic source.

Rockfalls did not occur in all areas characterized by suitable and favorable conditions for the generation of slope movements (broken brecciated rock mass, suitable geometry of discontinuities, steep slopes etc.). They were observed in the neotectonic graben that was activated by the earthquake and also north and northwest of it. They were due to the intense and multiple fracturing and the intense tectonic deformation along the reactivated faults resulting in a dense net of discontinuities and sectors of decreased cohesion and formations loosening. They were also attributed to the additional instantaneous shear stress than the earth- quake enforced on the stress field of the area. On the contrary, no rockfalls were observed on brecciated rock mass on steep slopes belonging to a neotectonic macrostructure (Kalathion Mt horst), which was not activated by the earthquake.

Hydrological anomalies, including changes in water discharge of springs and spring water turbidity, were temporary and of local character.

The maximum ESI 2007 intensity value has been evaluated as IX. It is almost totally assigned to specific locations mainly and strongly related to the presence of active faults and fault zones, the reactivation of faults and the intense morphology and the steep slopes (morphological slope $>50 \%$ ) observed east of, and along, the active Nedon fault zone (Figure 4). More specifically, these locations are: (a) the area of the Elaeochori village, where the active E-W striking Xerilas fault zone is located, bounding the southern margin of the activated Dimiova-Perivolakia graben, (b) the area of the Perivolakia and the Kato Karveli villages, where the active NW-SE striking Kato Karveli-Venitsa fault zone is located, bounding the northern margin of the active Dimiova-Perivolakia graben and (c) the area between and west of the Karveli and Ladas villages, where the reactivation of faults generated many rockfalls.

Intensity IX $\mathrm{IXSI}_{\mathrm{E} 2007}$ is also assigned for the strongest aftershock (September 15, 1986, Ms=5.4) based on reactivation of faults and rockfalls observed in the area around the Tzirorema gorge developed along the NESW trending part of Tzirorema River with steep slopes $(>50 \%)$ and rugged morphology.

The spatial distribution of structural damage caused by the September 13, 1986, Kalamata earthquake was non-uniform, selective and limited to an area of triangular shape, which is the Dimiova-Perivolakia graben, neotectonically defined to the south by the active Xerilas fault zone, to the east by the active Arachova fault zone and to the west by the active Nedon fault zone (Figure $2 \mathrm{~b}$ ) and it can also be regarded as a transitional area between the Kalamata-Kyparissia neotectonic basin and the neotectonic horsts of Asprochoma-Koutalas to the north and the Kalathion Mt to the south. On the contrary, in the Messene ( $\mathrm{VI}_{\text {EMS-98 }}$ ) and the Verga $\left(\mathrm{VI}_{\text {EMS-98 }}\right)$ areas, damage of that size were not observed because these areas belong to different neotectonic macrostructures (Kato Messinia basin and Kalathio Mt horst respectively) (Figure 2b) that were not reactivated during the 1986 Kalamata earthquake sequence.

Different EMS-98 intensities are observed between villages located at the western part of the study area (Figure 6). In particular, intensity $\mathrm{VI}_{\mathrm{EMS}-98}$ is assigned to the villages located at the western part of the study 
area (Thouria, Aithaia, Epia, Anthia, Kato Ampheia, Ano Ampheia), while intensity VIII ${ }_{\text {EMS-98 }}$ is assigned to the villages located southwest of it and particularly the Laeika and the Asprochoma villages (Figure 6). The first are founded on Pliocene marine formations consisting of conglomerates in the lower beds and marls in the upper beds, while the latter on old Pleistocene talus cones consisting of conglomerates and breccia in a red siliceous material [Mariolakos et al. 1986, Psonis 1986]. From the type and the distribution of EEE, it is also concluded that reactivation of faults was observed in the Laeika-Asprochoma area, while in the other area no significant EEE were induced by the September 13, 1986, Kalamata earthquake (Figure 3). Thus, this difference in the seismic intensities could be attributed to the geotechnical differences of geological formations of each region as well as to the reactivation of faults observed in the Laeika-Asprochoma area.

From the abovementioned spatial distribution of structural damage, it is concluded that areas belonging to neotectonic macrostructures and mainly to the marginal active fault zones are not suitable for construction foundation as the frequency and the density of the tectonic discontinuities should be great compared to other areas. They greatly influence the physical and mechanical characteristics of the rock-mass and most of them have the characteristics of active ones and it is most likely expected to be reactivated by a future earthquake. The Elaeochori and the Kato Karveli villages as well as the Kalamata city, where the $\mathrm{IX}_{\mathrm{EMS}-98}$ value was assigned, are built on such zones. The Elaeochori village for example has been built close to the active Xerilas fault zone (XFZ), which bounds the southern margin of the activated Dimiova-Perivolakia graben. The Kato Karveli village is founded close to the active Kato Karveli-Venitsa fault zone (KKVFZ). The city of Kalamata has been built at the crossing of the prolongation of two such big active fault zones, namely the Xerilas and the Nedon fault zones.

From the comparison of the EMS-98 seismic intensities with the seismic intensities reported by Elnashai et al. [1987], Gazetas et al. [1990] and Leventakis et al. [1992], it is concluded that the maximum seismic intensity IX derived from the application of the EMS-98 scale to the September 13 Kalamata earthquake is in agreement with the VIII+ seismic intensity on the IMM or EMS 1992 scale reported by Elnashai et al. [1987] and Gazetas et al. [1990]. Moreover, the intensity IX $\mathrm{EMS}-98$ for the city of Kalamata and the intensity IX $\mathrm{EMS}-98_{\text {for }}$ the Fares area in its eastern part are also in agreement with the intensity IX-X assigned to the Kalamata city and reported by Leventakis et al. [1992].

Based on the application of both ESI 2007 and
EMS-98 scales in the September 13, 1986, Kalamata earthquake, it is concluded that they both fit in with the neotectonic regime of the area. This is due to the fact that the maximum seismic intensity values are observed within the Dimiova-Perivolakia graben activated by the earthquake and are assigned to sites located close to the active marginal fault zones defining the boundaries of this structure and reactivated faults of the study area.

Seismic intensities based on the EMS-98 scale were assigned to settlements located: (a) within the activated Dimiova-Perivolakia graben, (b) in the southern coastal and hilly part of the affected area west of the Kalathion Mt horst, which was not reactivated, and (c) in the eastern lowland part of the Kato Messinia basin, particularly in the area of the Messene, Thouria and Ampheia villages (Figure 6).

Seismic intensities based on the EEE and the ESI 2007 scale were assigned not only in the above mentioned sites but also in different sparsely populated sections of the affected area. These sections are located north of the activated Dimiova-Perivolakia graben and around the active E-W trending Xerilas River (Figure 4), where no settlements exist and consequently no structural damage occurred, but considerable EEE were observed.

From the abovementioned, it becomes apparent that the ESI 2007 scale worked towards reducing discrepancies between the EEE and the damage pattern as it complemented the damage-based EMS-98 seismic intensities by evaluating seismic intensity solely from the EEE without the influence by human parameters such as effects on humans and the manmade environment. Thus, the integration of ESI 2007 scale with the EMS98 scale provided a completed picture of the strength and the effects of the September 13, 1986, Kalamata earthquake on the natural and the manmade environment of the affected area. Moreover, it contributed to a better picture of the earthquake scenario and represents a useful and reliable tool for the seismic hazard assessment, the prevention including mitigation strategies, community preparedness and response planning as well as the management of a future event of similar or larger magnitude.

Furthermore, the application of the ESI 2007 scale to the September 13, 1986, Kalamata earthquake contributes to the enlargement of the EEE dataset from earthquakes of the western part of the Peloponnese and the comparison of not only earthquakes of different tectonic settings, but also future, recent and historical events that are already known to have taken place in the SW Peloponnese. Hence, the use of the ESI 2007 scale and the EEE for seismic intensities assignments offers higher spatial resolution and coverage as well as expan- 
sion of the time window for seismic hazard assessment up to tens of thousands of years in order to reduce the uncertainty implied in the attenuation laws and eventually in the seismic hazard maps and compile an ESI 2007 intensity attenuation relationship, which should be one of the future goals for seismic hazard assessment.

Acknowledgements. Professor Ioannis Fountoulis sadly passed away $(16 / 2 / 2013)$ before the publication of this paper. It is a privilege to have known him as a scientist, a mentor and a friend. He will be forever missed and never forgotten. The anonymous reviewers are acknowledged for their constructive comments and helpful suggestions that improved the paper.

\section{References}

Anagnostopoulos, D., D. Rinaldis, V. Lekidis, V. Margaris and N. Theodoulidis (1987). The Kalamata, Greece, earthquake of September 13, 1986, Earthquake Spectra, 3, 365-402.

Angelier, J., N. Cyberis, X. Le Pichon, E. Barner and P. Huchon (1982). The tectonic development of the Hellenic Arc and the Sea of Crete: a synthesis, Tectonophysics, 86, 159-196.

Aubouin, J., M. Bonneau, J. Davidson, P. Le Boulenger, S. Matesco and A. Zambetakis (1976). Esquisse structural de l'arc égéen externe: des Dinarides aux Taurides, Bulletin de la Société Géologique de France, 18, 327-336.

Castilla, R.A., and F. Audemard (2007). Sand blows as a potential tool for magnitude estimation of pre-instrumental earthquakes, Journal of Seismology, 11, 473-487.

Dengler, L., and R. McPherson (1993). The 17 August 1991 Honeydaw earthquake north coast California: a case for revising the Modified Mercalli Scale in sparsely populated areas, B. Seismol. Soc. Am., 83, 1081-1094.

Dowrick, D.J. (1996). The Modified Mercalli earthquake intensity scale - Revisions arising from recent studies of New Zealand earthquakes, Bulletin of the New Zealand Society for Earthquake Engineering, 29 (2), 92-106.

Earthquake Planning and Protection Organization (EPPO). Kalamata earthquake 1986 (IX), available at http: / / www.oasp.gr/node / 672 (last accessed August 2012).

Elnashai, A.S., and K. Pilakoutas (1986). The Kalamata (Greece) earthquake of 13 September 1986, Engineering Seismology and Earthquake Engineering Report no. ESEE 9/86, Imperial College, UK, December 1986.

Elnashai, A., K. Pilakoutas, N. Ambraseys and I. Lefas (1987). Lessons learnt from the Kalamata (Greece) earthquake of 13 September 1986, European Earth- quake Engineering, 1, 11-19.

Elnashai, A.S., K. Pilakoutas, J.J. Bommer and S. Ledbetter (1988). Comparison of damage due to two recent earthquakes: San Salvador and Kalamata (Greece), 9th World Conference on Earthquake Engineering (Tokyo-Kyoto, Japan, 1988), VIII, 963-968.

Esposito, E., S. Porfido, G. Mastrolorenzo, A.A. Nikonov and L. Serva (1997). Brief review and preliminary proposal for the use of ground effects in the macroseismic intensity assessment, In: Ye Hong (ed.), Proceedings 30th International Geological Congress (Beijing, China, August 4-14, 1996), VSP, Utrecht, The Netherlands, 5, 233-243.

Fardis, M. (1987). Evaluation of damage to structures in the Kalamata earthquake, Research Report University of Patras, Greece, 1987 (in Greek).

Fountoulis, D., and K. Grivas (1989). Microtectonic study of the seismic fractures of Kalamata (earthquake period of September 1986), In: Proceedings of the 4th Congress of the Geological Society of Greece, Bulletin of the Geological Society of Greece, 23 (3), 259-274 (in Greek with French abstract).

Fountoulis, I. (2004). The neotectonic macrostructures and the geological basement, the main factors controlling the spatial distribution of the damage and geodynamic phenomena resulting from the Kalamata (13 September 1986) and Athens (7 September 1999) earthquakes, In: E.L. Lekkas (ed.), Advances in Earthquake Engineering, Earthquake Geodynamics - Seismic Case Studies, Wit Press, 12, 45-63.

Fountoulis, I., and I. Mariolakos (2008). Neotectonic folds in the central-western Peloponnese (Greece), Zeitschrift der Deutschen Gesellschaft für Geowissenschaften (Z. dt. Ges. Geowiss. ZDGG), 159 (3), 485-494.

Galanopoulos, A. (1947). The seismicity in Messinia province, Annales Géologiques des Pays Hélléniques, 1, 38-59.

Gazetas, G., P. Dakoulas and A. Papageorgiou (1990). Local soil and source-mechanism effects in the 1986 Kalamata (Greece) earthquake, Earthquake Engineering and Structural Dynamics, 19, 431-456.

Gosar, A. (2012). Application of Environmental Seismic Intensity scale (ESI 2007) to Krn Mountains 1998 $\mathrm{Mw}=5.6$ earthquake (NW Slovenia) with emphasis on rockfalls, Nat. Hazards Earth Syst. Sci., 12, 16591670.

Grünthal, G., ed. (1998) European Macroseismic Scale 1998 (EMS-98), Cahiers du Centre Européen de Géodynamique et de Séismologie 15, Centre Européen de Géodynamique et de Séismologie, Luxembourg, 99 pp.

Guerrieri, L., and E. Vittori, eds. (2007). Intensity scale 
ESI 2007, Memorie descrittive della Carta Geologica d'Italia, 74, $41 \mathrm{pp}$.

Guerrieri, L., R. Tatevossian, E. Vittori, V. Comerci, E. Esposito, A. M. Michetti, S. Porfido and L. Serva (2007). Earthquake environmental effects (EEE) and intensity assessment: the INQUA scale project, Bollettino della Società Geologica Italiana, 126, 375-386.

Hancox, G.T., N.D. Perrin and G.D. Dellow (2002). Recent studies of historical earthquake-induced landsliding, ground damage, and MM intensity in New Zealand, Bulletin of the New Zealand Society for Earthquake Engineering, 35 (2), 59-95.

Jacobshagen, V., F. St Durr, F. Kockel, K.O. Kopp, G. Kowalczyk, H. Berkhermer and D. Buttner (1978). Structure and geodynamic evolution of the Aegean region, In: H. Closs, D. Roeder and K. Scmidt (eds.), Alps, Apennines and Hellenides, E. Schweizerbartsche Verlagsbuchhandlung, Stuttgart, 536-564.

Ladas, I., I. Mariolakos and I. Fountoulis (2004). The neotectonic deformation of Pylia (SW Peloponnese, Greece), In: Proceedings of the 10th Congress of the Geological Society of Greece, Thessaloniki, Bulletin of the Geological Society of Greece, 36 (4), 1652-1661.

Le Pichon, X., and J. Angelier (1981). The Aegean Sea, Philosophical Transactions of the Royal Society of London, A300, 357-372.

Leventakis, G., V. Lekidis, Ch. Papaioannou, S. Zacharopoulos, G. Tsokas and A. Kiratzi (1992). Equal-Intensity contour map for the city of Kalamata due to September 1986 earthquake, In: Proc. 1st Hellenic Conf. of Earthquake Engin. and Engin. Seismology, 2, 321-330 (in Greek).

Lyon-Caen, H., R. Armijo, J. Drakopoulos, J. Baskoutas, N. Delibassis, R. Gaulon, V. Kouskouna, J. Latoussakis, K. Makropoulos, P. Papadimitriou, D. Papanastassiou and G. Pedotti (1988). The 1986 Kalamata (South Peloponnese) earthquake: Detailed study of a normal fault, evidences for east-west extension in the Hellenic arc, J. Geophys. Res., 93, 14967-15000.

Marcopoulou-Diacantoni, A., M.R. Mirkou, I. Mariolakos, E. Logos, S. Lozios and I. Fountoulis (1989). Stratigraphic observations in the post alpine deposits in Thouria-Ano Amfia area (Messinia Province, Greece) and their neotectonic interpretation, In: Proceedings of the 4th Congress of the Geological Society of Greece, Bulletin of the Geological Society of Greece, 23 (3), 275-295 (in Greek with English abstract).

Mariolakos, I., V. Sabot, A. Alexopoulos, G. Danamos, E. Lekkas, E. Logos, S. Lozios, A. Mertzanis and I. Fountoulis (1986). Microzonic study of Kalamata, (Geomorphology, Geology, Neotectonics), Earth
Planning Protection Organization, Report, 110, Athens (in Greek).

Mariolakos, I., V. Sabot, E. Logos, S. Lozios and I. Fountoulis (1987). On the Geomorphology-GeologyNeotectonics \& Seismotectonics of Kalamata area, Field trip guide for the IFAQ-UNESCO (1987) Seminars, "Seminars on Quaternary Deposits in Tectonic Active Areas".

Mariolakos, I. (1988). The application of the Darcy's Law in closed geomorphological and hydrogeological systems, Example: the basin of Ano Messinia (SW Peloponnisos), In: Proceedings of the 3rd Congress of the Geological Society of Greece, Bulletin of the Geological Society of Greece, 20 (3), 77-96 (in Greek with English abstract).

Mariolakos, I., I. Fountoulis, E. Logos and S. Lozios (1989). Surface faulting caused by the Kalamata (Greece) earthquakes (13.9.1986), Tectonophysics, 163, 197-203.

Mariolakos, I. (1990). Outline on the morphotectonic evolution of Messinia during the neotectonic period, In: M. Moutsoulas and Ch. Kontoes (eds.), Proceedings from Workshop and Seminar on the Messinia Project of the European Collaborative Programme, Eugenidis Foundation (Athens, November 19-20, 1990), 155-163.

Mariolakos, I. (1991). Prediction of natural mass movement in tectonically-active areas, In: M.E. AlmeidaTeixeira, R. Fantechi, R. Oliveira and A. Gomes Coelho (eds.), Proceedings of the European School of Climatology and Natural Hazards "Natural hazards and engineering geology - Prevention and control of landslides and other mass movements" (Lisbon, March 28 - April 5, 1990), 69-81.

Mariolakos, I., I. Fountoulis and S. Nassopoulou (1992). The influence of the neotectonic macrostructures, fractures and the geological basement in the distribution of the damages in the Kalamata earthquake (13-9-1986), In: Proceedings of the 1st Greek Congress on Anti-seismic Engineering and Technical Seismology, Technical Chamber of Greece, 1, 55-68 (in Greek with English abstract).

Mariolakos, I., H. Schneider, H., I. Fountoulis and N. Vouloumanos (1993). Paleogeography, sedimentation and neotectonic implications at the Kambos depression and Kitries Bay area (Messinia, Peloponnese, Greece), In: Proceedings of the 6th Congress of the Geological Society of Greece, Bulletin of the Geological Society of Greece, 28 (1), 397-413 (in Greek with English abstract).

Mariolakos, I., I. Fountoulis, A. Marcopoulou-Diacantoni and M.R. Mirkou (1994). Some remarks on the kinematic evolution of Messinia province (SW Pelo- 
ponnese) during the Pleistocene based on neotectonic, stratigraphic and paleoecological observations, Münstersche Forschungen zur Geologie und Paläontologie, 76, 371-380.

Mariolakos, I., and I. Fountoulis (1998). Is it safe to build on fault surfaces in a seismically active area? The case of Eleohori village (SW Peloponnessos, Greece), In: Proceedings of the 8th IAEG Congress (Vancouver, Canada, September 21-26, 1998), 665-670.

Mariolakos, I., and I. Fountoulis (2004). The current geodynamic regime in the Hellenic area, In: I. Mariolakos, I. Zagorchev, I. Fountoulis and M. Ivanov (eds.), Neotectonic transect Moesia-Apulia. Field trip Guide book - B26, 32nd, International Geological Congress (Florence), $72 \mathrm{pp}$.

Michetti, A.M., E. Esposito, A. Gurpinar, B. Mohammadioun, J. Mohammadioun, S. Porfido, E. Rogozhin, L. Serva, R. Tatevossian, E. Vittori, F. Audemard, V. Comerci, S. Marco, J. McCaplin, N.A. Morner (2004). The INQUA scale: an innovative approach for assessing earthquake intensities based on seismically induced ground effects in natural environment, Memorie descrittive della Carta Geologica d'Italia, Special paper edited by E. Vittori and V. Comerci, 67, $46 \mathrm{pp}$.

Michetti, A.M., E. Esposito, L. Guerrieri, S. Porfido, L. Serva, R. Tatevossian, E. Vittori, F. Audemard, T. Azuma, J. Clague, V. Comerci, A. Gürpinar, J. Mccalpin, B. Mohammadioun, N. A. Mörner, Y. Ota and E. Roghozin (2007). Environmental Seismic Intensity Scale 2007 - ESI 2007, In: L. Guerrieri and E. Vittori (eds.), Intensity Scale ESI 2007, Memorie descrittive della Carta Geologica d'Italia, 74, 7-54.

Papanikolaou, D., V. Lykousis, G. Chronis and P. Pavlakis (1988). A comparative study of neotectonic basins across the Hellenic arc: the Messiniakos, Argolikos, Saronikos and Southern Evoikos Gulfs, Basin Research, 1, 167-176.

Papazachos, V., A. Kiratzi, B. Karacostas, D. Panagiotopoulos, E. Scordilis and D. Mountrakis (1988). Surface fault traces, fault plane solution and spatial distribution of the aftershocks of the September 13, 1986 earthquake of Kalamata (Southern Greece), Pure and Applied Geophysics, 126 (1), 55-68.

Papazachos, B., and C. Papazachou (2003). The Earthquakes of Greece, Editions ZITI Thessaloniki, Greece, 2003.

Pavlakis, P., D. Papanikolaou, G. Chronis, B. Lykousis and G. Anagnostou (1989). Geological structure of inner Messiniakos Gulf, In: Proceedings of the 4th Congress of the Geological Society of Greece, Bulletin of the Geological Society of Greece, 23 (3), 333-347.
Porfido, S., E. Esposito, L. Guerrieri, E. Vittori, G. Tranfaglia and R. Pece (2007). Seismically induced ground effects of the 1805, 1930 and 1980 earthquakes in the Southern Apennines, Italy, Bolletino della Società Geologica Italiana, 126, 333-346.

Psonis, K. (1986). Geological map of Greece, Kalamata sheet, scale 1:50,000, Geological Survey of Greece, Athens.

Reicherter, K., A. Michetti and P.G. Silva, eds. (2009). Palaeoseismology: Historical and Prehistorical Records of Earthquake Ground Effects for Seismic Hazard Assessment, Geological Society of London, Special Publications, 316, London, U.K. Publ., 316, 55-71.

Serva, L. (1994). Ground effects in the intensity scales, Terra Nova, 6, 414-416.

Serva, L., E. Esposito, L. Guerrieri, S. Porfido, E. Vittori and V. Comerci (2007). Environmental effects from five hystorical earthquakes in Southern Apennines (Italy) and macroseismic intensity assessment: Contribution to INQUA EEE Scale Project, Quaternary Int., 173-174, 30-44.

Silva, P.G., M.A. Rodríguez Pascua, R. Pérez-López, T. Bardaji, J. Lario, P. Alfaro, J.J. Martínez-Díaz, K. Reicherter, J. Giménez García, J. Giner, J.M. Azañón, J.L. Goy and C. Zazo (2008). Catalogacion de los efectos geologicos y ambientales de los terremotos en Espana en la Escala ESI 2007 y su aplicacion a los estudions paleosismologicos, Geotemas, 6, 1063-1066.

Stiros, S., and V. Kontogianni (2008). Modelling of the Kalamata (SW Greece) earthquake faulting using geodetic data, Journal of Applied Geodesy, 2, 179185; doi:10.1515/JAG.2008.020.

Tselentis, G.-A, J. Drakopoulos and K. Makropoulos (1988). Site effects on seismograms of local earthquakes in the Kalamata region, Southern Greece, B. Seismol. Soc. Am., 78 (4), 1597-1602.

\footnotetext{
${ }^{\star}$ Corresponding author: Spyridon D. Mavroulis, National and Kapodistrian University of Athens, Faculty of Geology and Geoenvironment, Department of Dynamic Tectonic Applied Geology, Panepistimiopolis, Athens, Greece; e-mail: smavroulis@geol.uoa.gr.

C 2013 by the Istituto Nazionale di Geofisica e Vulcanologia. All rights reserved.
} 